\title{
Influence of high temperature on the reproductive biology of dry edible bean (Phaseolus
}

\author{
vulgaris L.)
}

Daiana Alves da Silva ${ }^{1 *} \odot$, Cecília Alzira Ferreira Pinto-Maglio ${ }^{2 \oplus}$, Érica Cristina de Oliveira ${ }^{2}$, Raquel Luiza de Moura dos Reis ${ }^{1}$, Sérgio Augusto Morais Carbonell1 ${ }^{\circledR}$, Alisson Fernando Chiorato ${ }^{1 \odot}$

IInstituto Agronômico - IAC/Centro de Análises e Pesquisa Tecnológica do Agronegócio dos Grãos e Fibras, Av. Dr. Theodureto de Almeida Camargo, 1500 - 13075-630 Campinas, SP - Brasil.

2Instituto Agronômico - IAC/Centro de Pesquisa de Recursos Genéticos Vegetais.

*Corresponding author <daiagrouel2002@hotmail.com>

Edited by: Leonardo Oliveira Medici

Received July 24, 2018

Accepted October 11, 2018
ABSTRACT: The aim of this study was to investigate the effect of heat stress on 12 bean genotypes through the analysis of their reproductive biology in terms of flowering, pollen viability, meiotic behavior, and production. Plants were grown in a climate chamber at $25-20^{\circ} \mathrm{C}$ (day and night) and at a high temperature treatment $37-26^{\circ} \mathrm{C}$ (day and night) from the vegetative (V4) development stage to physiological maturity. The experimental design was $2 \times 12$ factorial arrangement with six replications and the factors consisted of heat treatments and genotypes. In three replications, the number of newly opened flowers was checked daily. At physiological maturity, the following traits were evaluated: percentage of pod set, number of pods, number of viable seeds, number of aborted seeds, 100 seed weight, and seed yield (g per plant). The other three replications were used to collect flowers to create slides to study viability of the pollen grain and analyze the meiotic behavior. The heat treatment factor significantly affected the following traits: total number of pollen grains, number of flowers, number of pods, pod set, number of viable seeds, 100 seed weight, and seed yield. The raised temperature reduced these variables, except for percentage of pod set, and increased meiotic irregularities. The mean values regarding seed yield were $16.39 \mathrm{~g}$ per plant for the control treatment and $7.46 \mathrm{~g}$ per plant under high temperature. IAC Imperador, FT Nobre, Pérola, BRS Estilo, and IAC Diplomata stood out for higher bean seed yield under increased temperature.

Keywords: common bean, heat stress, pollen viability, meiosis, seed yield

\section{Introduction}

In Latin America and in Africa, dry bean (Phaseolus vulgaris L.) production is highly vulnerable to the effects of climate change, mainly higher temperatures and drought. Recent studies on climate modeling suggest that over the next decades, higher temperature will be the main threat to bean production with possible drastic reductions in planted area by 2050 (CGIAR, 2015).

Various research groups have evaluated the response of different species to high temperature. Hatfield and Prueger (2015) emphasize that the effect of extreme temperatures on plant development has not been treated as the main effect during the pollination phase and that plants exposure to heat in this phase has considerable impact on yield for all plant species. Ofir et al. (1993) studied six bean cultivars and observed a reduction in number of pods and seeds under exposure to $32 / 27^{\circ} \mathrm{C}$ (day/night). The authors reported that yield reduction was caused by abscission of flower buds, flowers, and newly formed pods and by failure to fertilize. Monterroso and Wien (1990) also verified that the pre-fertilization period is more sensitive to heat stress, causing roughly $82 \%$ of abscission of newly formed pods.

Omae et al. (2012) report that genotypic differences for tolerance to high temperature in bean are found in morphophysiological traits, such as partitioning, plant-water relations, photosynthetic and growth param- eters of the shoots, which are related to reproductive responses. Heat tolerant cultivars normally have greater allocation of biomass to pods and greater pod set in the branches.

According to Ernest et al. (2017), heat-related yield loss in lima bean is partially due to reduction of the number of pollen grains released for fertilization. The effects of high temperature on production and release of pollen grains are determined by the conditions to which the flower is subject. Other factors, such as pollen viability and pollen tube growth can also play a role in response to heat stress.

In this context, this study investigated the effects of stress caused by high temperature on 12 bean genotypes, studying their reproductive biology through monitoring flower production, analysis of pollen grain viability, meiotic behavior, and pod set, as well as their yield potentials.

\section{Materials and Methods}

Twelve genotypes of bean were grown in $5 \mathrm{~L}$ pots filled with a 3:1 soil and sand mixture, with drip irrigation, keeping the soil matric potential near -40 Centibars $/ \mathrm{kPa}$. Twenty days after transplantation, cover fertilization was applied, consisting of $150 \mathrm{~kg} \mathrm{ha}^{-1} \mathrm{~N}$ with urea. The genotypes evaluated in this study were 1-SEA 5, 2-IAC Imperador, 3-SER 16, 4-Pérola, 5-IAC Milênio, 6-FT Nobre, 7-BRS Estilo, 8-IAPAR 81, 9-IAC Diplomata, 10-IPR Tangará, 11-BRS Agreste, and 12-IAC Sintonia. 
The plants under high temperature and control treatments were sown in a successive manner in a growing chamber. Both treatments received the same lighting and photoperiod conditions; however, at different temperatures, that is, a 12-h photoperiod, photosynthetic photon flux density (PPFD) of $600 \mu \mathrm{mol} \mathrm{m}^{-2} \mathrm{~s}^{-1}$, and temperature $25 / 20{ }^{\circ} \mathrm{C}$ (day/night). For the treatment with high temperature, $25-20{ }^{\circ} \mathrm{C}$ (day and night) occurred up to the pre-flowering stage, and then the temperature of the environment was changed to $37-26{ }^{\circ} \mathrm{C}$ (day and night) up to physiological maturity.

The experimental design was $2 \times 12$ factorial arrangement with six replications, with the first factor consisting of high temperature and control treatments. The second factor consisted of 12 genotypes and each replication consisted of a plant per pot. Three replications were used for pollen collection and other three replications to assess flower production, production components, and bean seed yield.

Flowering was monitored by daily by counting newly opened flowers during the flowering period (NF). The same replications were used to assess the number of pods $(\mathrm{NP})$, calculating the percentage of pod set (PDS) in relation to the number of flowers. In addition, production components were evaluated: total number of seeds per plant (NSP), number of aborted seeds per plant (empty locules) (NAS), 100 seed weight (100SW), and bean seed yield (g per plant) (BSY).

For the analysis of pollen grain viability, both in the germination and staining tests, two newly opened flowers were collected to prepare two slides per replication, that is, each replication was composed of the arithmetic mean of the counts from both slides.

\section{Germination of pollen in vitro}

The collected pollen grains were detached from the anthers of one newly flower with a brush and deposited on slides containing culture medium $(20 \mathrm{~mL}$ of distilled water, $0.32 \mathrm{~g}$ of sucrose, and $0.22 \mathrm{~g}$ of agar) (Conger, 1953). The slides were kept in a laboratory oven at $29^{\circ} \mathrm{C}$ for $17 \mathrm{~h}$. Afterwards, the number of germinated pollen grains $(\mathrm{PG})$ in relation to the total number of pollen grains (TNP) was determined. The grains with a pollen tube longer than the grain diameter were considered viable. Grains were observed and counted on the entire slide.

\section{Pollen viability by staining}

To determine pollen viability by staining, the anthers of the newly collected flower buds were removed and macerated on the slide containing two drops $(50 \mu \mathrm{L})$ of Alexander's stain (Alexander, 2009). Afterwards, the macerated material was covered with a glass plate and then analyzed under an optical microscope at 400X magnification. The viable pollen grains (PV) and non-viable pollen grains (PNV) were calculated in relation to the total number of pollen grains stained (TNPS). Pollen grains were considered viable when they had a purple color, and non-viable when they were without content and/or without color. The pollen grains in 10 random areas of each slide were calculated.

\section{Measuring pollen grains}

The slides used for determining pollen viability were also used to check pollen size (PS). Two slides were used and 100 grains of each genotype per treatment were measured and the total count was considered for the analysis of variance. Pollen size was assessed under an optical microscope at $100 \mathrm{X}$ magnification with the aid of the CellF program (OLYMPUS).

\section{Meiotic behavior}

The meiotic behavior was studied in five genotypes, namely, IPR Tangará, IAC Sintonia, SEA 5, IAPAR 81 (which exhibited significant difference by the staining viability test for pollen size), and IAC Milênio (which exhibited lower yield performance under high temperature).

Flower buds of different sizes were collected and immediately fixed in Carnoy solution 3:1 (ethyl alcohol:acetic acid), vacuum infiltrated for $5 \mathrm{~min}$ to increase the penetration efficiency of the fixing solution into the tissues and then stored in a freezer at $-20{ }^{\circ} \mathrm{C}$ until preparation of the slides. To prepare the slides, the anthers were excised from the flower bud with a magnifying glass and tweezers, placed on a slide, and then stained with two drops of $1.2 \%$ carmine acetic and macerated, for later analysis of meiotic behavior.

The meiotic index (MI) was estimated considering the relation between the total of normal tetrads and the total of abnormal post-meiotic products, as proposed by LOVE (1951), in which MI = (no. of normal tetrads $\div$ no. of abnormal post-meiotic products $) \times 100$. Tetrads containing four microspores of the same size was considered normal and any difference (monad, dyad, triad, and polyad) was considered abnormal.

\section{Data analysis and capturing images}

All slides were analyzed in a light microscope (Olympus BX51TF) equipped with a digital camera (Olympus - DP72). The images were captured with the Cell $\mathrm{F}$ program and the images were adjusted with the Adobe Photoshop CS6 program.

\section{Statistical analyses}

The data were analyzed by individual analysis of variance in $2 \times 12$ factorial arrangement, followed by the Scott-Knott mean comparison test at $5 \%$ probability and transformed when the data were non-standardized.

\section{Results}

\section{Pollen grain traits}

The analysis of variance of pollen grain traits (Table 1) shows a significant effect of heat treatment only for total number of pollen grains (TNP) and pollen grain size (PS). Significant effects were also observed in the heat treatment $\times$ genotype interaction for all the vari- 
Table 1 - Summary of analyses of variance regarding viability of pollen grain of 12 dry edible bean genotypes by the methods of staining using Alexander's stain, and analyses regarding germination of the pollen grain on slides containing culture medium, flower production and yield components of 12 genotypes of dry edible bean grown under two heat treatments, control temperature (C) and high temperature (HT).

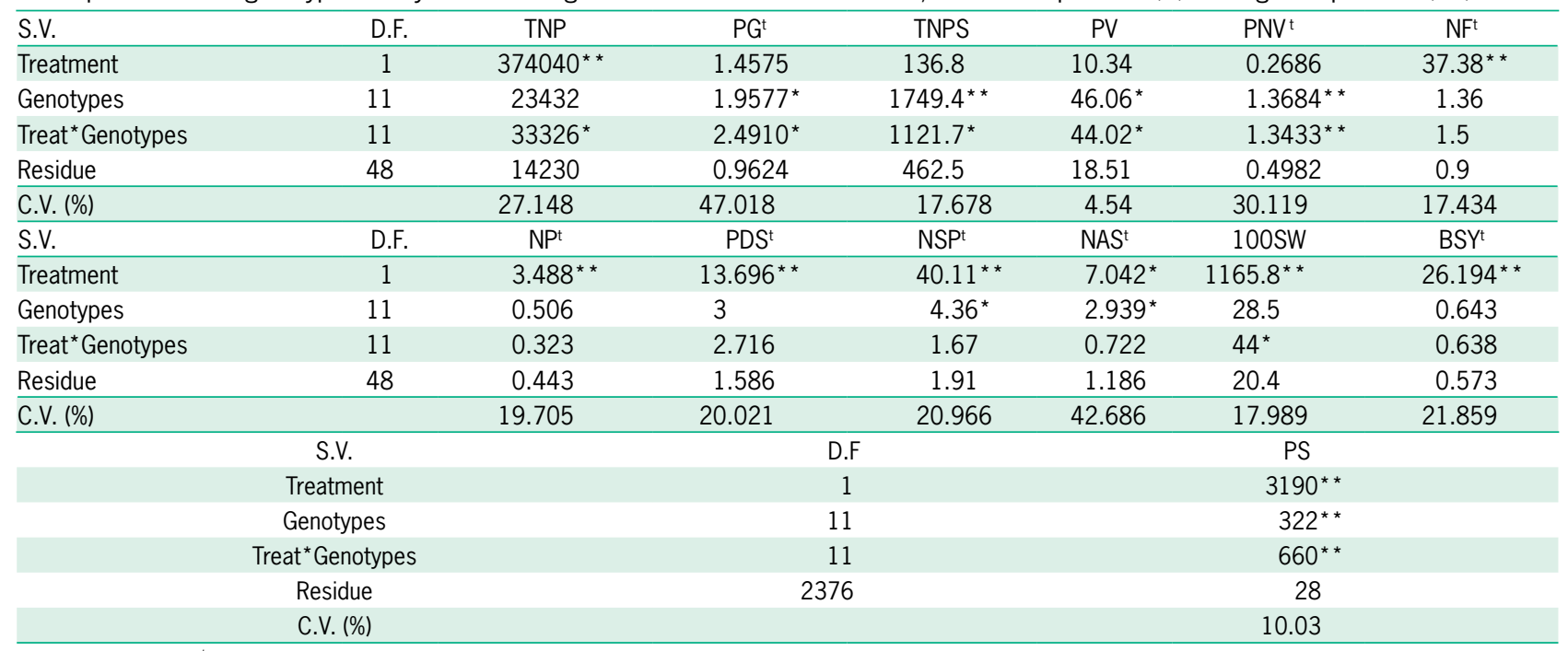

tData transformed $\sqrt{ } \mathrm{x}+1 .{ }^{*},{ }^{*}$ * Significant at 0.05 and 0.01 by $F$ test. S.V. $=$ Source of variance; $D . F .=$ Degree of freedom; TNP $=$ Total number of pollen grain; $P G=$ Germinated pollen; TNPS = Total number of pollen grain stained; PV = Viable pollen grains; PNV = Non-viable pollen grains; NF $=$ Number of flowers; $N P=$ Number of pods; PDS = Pod set; NSP = Number of seeds per pod; NAS = Number of aborted seeds; 100SW = Hundred seed mass; BSY = Bean seed yield; PS = Pollen size.

ables studied. Pronounced effects related to the genotype factor were observed for number of pollen grains germinated (PG), total number of pollen grains (TNP), number of viable pollen grains (PV), and number of nonviable pollen grains (PNV).

The variable TNP, when applied to the germination technique, showed mean values 511.47 grains of pollen for the control (C) treatment and 367.32 pollen grains for the high temperature (HT) treatment, meaning that the high temperature treatment reduced the number of pollen grains by $28 \%$ on average (Table 2). Under high temperature, the mean amplitude observed regarding pollen grain formation was from 474.25 for Pérola genotype to 255.5 for SER 16 genotype. In addition, comparing pollen grain formation in the control and HT treatment, significant differences were observed between the treatments for genotypes SER 16, IAC Sintonia, and IAC Imperador, as these genotypes were more affected by high temperature, showing reductions $62 \%$, $61 \%$, and $56 \%$ in pollen production, respectively.

In relation to $P G$, a low germination rate was observed in both heat treatments, with mean values of $4 \%$ for the control and $5 \%$ for the HT treatments. The mean values did not differ statistically, despite an increase of $33 \%$ in germination in the HT treatment in relation to the control (Table 2). Furthermore, the means test showed differences between the treatments for genotypes SER 16, IAC Sintonia, and IPR Tangará, meaning that, at high temperature, the first two treatments had pronounced increases, whereas IPR Tangará had a reduction, with mean values of increase and reduction of $1675 \%, 437 \%$, and $-95 \%$, respectively.
The amplitude observed in the HT treatment for the PG variable ranged from $17 \%$ for SER 16 genotype, which had the highest germination rate, to $0.3 \%$ for Pérola genotype, which had the lowest rate. Genotypes SER 16, IAC Sintonia, SEA 5, IAPAR 81, and IAC Diplomata also stood out with high pollen grain germination rates.

The mean total number of pollen grains assessed by the staining technique (TNPS) was 120.27 for the control and 123.03 for the HT treatment. These mean values did not differ from each other by the Scott-Knott test at $5 \%$ probability (Table 2). Differences were found in the HT treatment for genotypes FT Nobre, IAC Diplomata, and BRS Estilo. In the control treatment, the first two genotypes had the highest mean values. At high temperature, the amplitude regarding the number of pollen grains ranged from 148 for IPR Tangará genotype to 79.83 for SER 16 genotype.

High percentages were found regarding the number of viable pollen grains (PV) analyzed in the staining test. The mean for the control treatment was $94 \%$ and $95 \%$ for the HT treatment (Table 2). Genotypes IPR Tangará and IAC Sintonia differed in the HT treatment. Under high temperature, the mean value of IPR Tangará decreased by $12 \%$, whereas IAC Sintonia increased by $14 \%$. In the control treatment, IAC Imperador genotype had the lowest PV value at $88 \%$, whereas IPR Tangará genotype exhibited the highest value at $98 \%$. Under high temperature, only IAC Imperador and IPR Tangará genotypes differed from the other genotypes and had viability lower than $90 \%$. The mean number of PNV observed was $6 \%$ in the control treatment and $5 \%$ in 
Table 2 - Scott-Knott mean comparison test $(p<0.05)$ in reference to the variables of pollen grain viability and size, flower production, and production components, and bean seed yield of 12 genotypes of dry edible bean grown under two heat treatments, control temperature (C) and high temperature (HT).

\begin{tabular}{|c|c|c|c|c|c|c|c|c|c|c|}
\hline \multirow{2}{*}{ Genotype } & \multicolumn{2}{|c|}{ TNP } & \multicolumn{2}{|c|}{ PDS } & \multicolumn{2}{|c|}{ TNPS } & \multicolumn{2}{|c|}{ PV } & \multicolumn{2}{|c|}{ PNV } \\
\hline & $C$ & HT & $C$ & HT & $C$ & HT & $C$ & HT & C & HT \\
\hline 1 & $344.00 \mathrm{bA}$ & $308.83 \mathrm{aA}$ & $10.72 \mathrm{aA}$ & $10.57 \mathrm{aA}$ & $89.17 \mathrm{aA}$ & $99.33 \mathrm{bA}$ & $96.70 \mathrm{aA}$ & $96.36 \mathrm{aA}$ & $3.30 \mathrm{bA}$ & $3.64 \mathrm{aA}$ \\
\hline 2 & $654.00 \mathrm{aA}$ & $288.00 \mathrm{aB}$ & $0.61 \mathrm{aA}$ & $0.59 \mathrm{bA}$ & $126.50 \mathrm{aA}$ & $116.00 \mathrm{bA}$ & $88.54 \mathrm{bA}$ & $88.96 \mathrm{bA}$ & $11.46 \mathrm{aA}$ & $11.04 \mathrm{aA}$ \\
\hline 3 & $678.50 \mathrm{aA}$ & $255.50 \mathrm{aB}$ & $0.96 \mathrm{aB}$ & $16.99 \mathrm{aA}$ & $107.83 \mathrm{aA}$ & $79.83 \mathrm{bA}$ & $95.84 \mathrm{aA}$ & $96.51 \mathrm{aA}$ & $4.16 \mathrm{bA}$ & $3.48 \mathrm{aA}$ \\
\hline 4 & $380.00 \mathrm{bA}$ & $474.25 \mathrm{aA}$ & $0.74 \mathrm{aA}$ & $0.29 \mathrm{bA}$ & $140.50 \mathrm{aA}$ & $137.67 \mathrm{aA}$ & $94.90 \mathrm{aA}$ & $95.53 \mathrm{aA}$ & $5.10 \mathrm{bA}$ & $4.47 \mathrm{aA}$ \\
\hline 5 & $586.83 \mathrm{aA}$ & $397.33 \mathrm{aA}$ & $3.97 \mathrm{aA}$ & $2.29 \mathrm{bA}$ & $117.00 \mathrm{aA}$ & $146.67 \mathrm{aA}$ & $92.31 \mathrm{bA}$ & $96.00 \mathrm{aA}$ & $7.69 \mathrm{aA}$ & $4.00 \mathrm{aA}$ \\
\hline 6 & $450.00 \mathrm{bA}$ & $311.50 \mathrm{aA}$ & $7.01 \mathrm{aA}$ & $2.11 \mathrm{bA}$ & $91.00 \mathrm{bB}$ & $136.17 \mathrm{aA}$ & $96.29 \mathrm{aA}$ & $97.66 \mathrm{aA}$ & $3.71 \mathrm{bA}$ & $2.35 \mathrm{aA}$ \\
\hline 7 & $599.16 \mathrm{aA}$ & $441.33 \mathrm{aA}$ & $2.08 \mathrm{aA}$ & $2.62 \mathrm{bA}$ & $132.50 \mathrm{aA}$ & $92.83 \mathrm{bB}$ & $97.29 \mathrm{aA}$ & $97.48 \mathrm{aA}$ & $2.71 \mathrm{bA}$ & $2.52 \mathrm{aA}$ \\
\hline 8 & $363.50 \mathrm{bA}$ & $336.00 \mathrm{aA}$ & $1.96 \mathrm{aA}$ & $9.41 \mathrm{aA}$ & $122.50 \mathrm{aA}$ & $105.17 \mathrm{bA}$ & $98.59 \mathrm{aA}$ & $96.75 \mathrm{aA}$ & $1.41 \mathrm{bA}$ & $3.25 \mathrm{aA}$ \\
\hline 9 & $440.33 \mathrm{bA}$ & $356.25 \mathrm{aA}$ & $1.03 \mathrm{aA}$ & $7.08 \mathrm{aA}$ & $103.33 \mathrm{bB}$ & $139.83 \mathrm{aA}$ & $90.31 \mathrm{bA}$ & $95.34 \mathrm{aA}$ & $9.69 \mathrm{aA}$ & $4.66 \mathrm{aA}$ \\
\hline 10 & $495.33 \mathrm{bA}$ & $429.16 \mathrm{aA}$ & $10.14 \mathrm{aA}$ & $0.55 \mathrm{bB}$ & $136.75 \mathrm{aA}$ & $148.00 \mathrm{aA}$ & $98.85 \mathrm{aA}$ & $87.10 \mathrm{bB}$ & $1.15 \mathrm{bB}$ & $12.90 \mathrm{aA}$ \\
\hline 11 & $534.33 \mathrm{aA}$ & $471.00 \mathrm{aA}$ & $6.89 \mathrm{aA}$ & $0.36 \mathrm{bA}$ & $157.33 \mathrm{aA}$ & $133.67 \mathrm{aA}$ & $97.46 \mathrm{aA}$ & $96.44 \mathrm{aA}$ & $2.54 \mathrm{bA}$ & $3.56 \mathrm{aA}$ \\
\hline 12 & $611.66 \mathrm{aA}$ & $338.66 \mathrm{aB}$ & $2.15 \mathrm{aB}$ & $11.55 \mathrm{aA}$ & $118.83 \mathrm{aA}$ & $141.17 \mathrm{aA}$ & $85.48 \mathrm{bB}$ & $97.53 \mathrm{aA}$ & $14.52 \mathrm{aA}$ & $2.47 \mathrm{aB}$ \\
\hline $\mathrm{C}$ & $511.47 \mathrm{~A}$ & & $4.02 \mathrm{~A}$ & & $120.27 \mathrm{~A}$ & & $94.38 \mathrm{~A}$ & & $5.62 \mathrm{~A}$ & \\
\hline \multirow[t]{2}{*}{ HT } & 367.32 B & & $5.37 \mathrm{~A}$ & & $123.03 \mathrm{~A}$ & & $95.14 \mathrm{~A}$ & & $4.862 \mathrm{~A}$ & \\
\hline & \multicolumn{2}{|c|}{ PS } & \multirow{2}{*}{ NF } & \multirow{2}{*}{ NP } & \multirow{2}{*}{ PDS } & \multirow{2}{*}{ NSP } & \multirow{2}{*}{ NAS } & \multicolumn{2}{|c|}{ 100SW } & \\
\hline Genotype & C & HT & & & & & & $C$ & HT & BSY \\
\hline 1 & $54.69 \mathrm{bA}$ & $45.71 \mathrm{cB}$ & $19.17 \mathrm{a}$ & $7 \mathrm{a}$ & $39.55 \mathrm{a}$ & $32.83 b$ & $3.00 \mathrm{~b}$ & $28.99 \mathrm{aA}$ & $24.3 \mathrm{aA}$ & $9.16 \mathrm{a}$ \\
\hline 2 & $51.12 \mathrm{cA}$ & $50.57 \mathrm{bA}$ & $33.83 \mathrm{a}$ & $13.33 \mathrm{a}$ & 39.83 a & $54.17 \mathrm{a}$ & $16.33 \mathrm{a}$ & $25.99 \mathrm{aA}$ & $18.29 \mathrm{aA}$ & $12.04 \mathrm{a}$ \\
\hline 3 & $54.51 \mathrm{bA}$ & $53.06 \mathrm{aA}$ & $31.00 \mathrm{a}$ & $10.83 \mathrm{a}$ & $44.09 a$ & $44.17 b$ & $4.00 \mathrm{~b}$ & $29.11 \mathrm{aA}$ & $20.49 \mathrm{aB}$ & $11.52 \mathrm{a}$ \\
\hline 4 & $51.97 \mathrm{cA}$ & $51.14 \mathrm{aA}$ & $31.17 \mathrm{a}$ & $11.00 \mathrm{a}$ & $36.13 \mathrm{a}$ & $42.67 \mathrm{~b}$ & $6.33 b$ & $28.89 \mathrm{aA}$ & $25.78 \mathrm{aA}$ & $11.87 \mathrm{a}$ \\
\hline 5 & $52.55 \mathrm{cA}$ & $52.98 \mathrm{aA}$ & $29.83 \mathrm{a}$ & $9.33 \mathrm{a}$ & $36.32 \mathrm{a}$ & $32.83 b$ & $5.50 \mathrm{~b}$ & $32.73 \mathrm{aA}$ & $22.85 \mathrm{aB}$ & 9.99 a \\
\hline 6 & $52.23 \mathrm{cA}$ & $51.39 \mathrm{aA}$ & $25.33 \mathrm{a}$ & $12.67 \mathrm{a}$ & $52.97 \mathrm{a}$ & $71.17 \mathrm{a}$ & $5.00 \mathrm{~b}$ & $24.2 \mathrm{aA}$ & $17.69 \mathrm{aA}$ & $15.60 \mathrm{a}$ \\
\hline 7 & $51.76 \mathrm{cA}$ & $52.82 \mathrm{aA}$ & $23.00 \mathrm{a}$ & $12.00 \mathrm{a}$ & $55.19 \mathrm{a}$ & $53.50 \mathrm{a}$ & $5.33 \mathrm{~b}$ & $31.82 \mathrm{aA}$ & $21.85 \mathrm{aB}$ & $15.00 \mathrm{a}$ \\
\hline 8 & $50.57 \mathrm{cB}$ & $52.54 \mathrm{aA}$ & $33.17 \mathrm{a}$ & $10.00 \mathrm{a}$ & $33.12 \mathrm{a}$ & $35.50 \mathrm{~b}$ & $12.50 \mathrm{a}$ & $25.2 \mathrm{aA}$ & $25.17 \mathrm{aA}$ & $8.85 a$ \\
\hline 9 & $57.01 \mathrm{aA}$ & 50.71 bB & $36.67 \mathrm{a}$ & $11.17 \mathrm{a}$ & $31.87 \mathrm{a}$ & $52.33 \mathrm{a}$ & $6.17 b$ & $29.48 \mathrm{aA}$ & $24.72 \mathrm{aA}$ & $14.99 \mathrm{a}$ \\
\hline 10 & 54.76 bA & $51.85 \mathrm{aB}$ & $32.83 \mathrm{a}$ & $9.83 \mathrm{a}$ & $27.98 \mathrm{a}$ & $37.50 \mathrm{~b}$ & $9.50 \mathrm{a}$ & $32.17 \mathrm{aA}$ & $14.76 \mathrm{aB}$ & $10.48 \mathrm{a}$ \\
\hline 11 & $58.04 \mathrm{aA}$ & 50.18 bB & $32.17 \mathrm{a}$ & $10.50 \mathrm{a}$ & $42.04 \mathrm{a}$ & $41.83 b$ & $1.33 \mathrm{~b}$ & $26.49 \mathrm{aA}$ & $21 \mathrm{aA}$ & $10.86 \mathrm{a}$ \\
\hline 12 & 54.82 bA & $51.77 \mathrm{aB}$ & $33.33 \mathrm{a}$ & $13.00 \mathrm{a}$ & $49.11 \mathrm{a}$ & $44.50 \mathrm{~b}$ & $8.50 \mathrm{a}$ & $34.62 \mathrm{aA}$ & $16.19 \mathrm{aB}$ & $13.18 \mathrm{a}$ \\
\hline $\mathrm{C}$ & \multicolumn{2}{|c|}{$53.6 \mathrm{~A}$} & $38.16 \mathrm{~A}$ & $12.5 \mathrm{~A}$ & $34.88 \mathrm{~A}$ & $55.69 A$ & $8.47 \mathrm{~A}$ & \multicolumn{2}{|c|}{$29.14 \mathrm{~A}$} & 16.39 \\
\hline HT & \multicolumn{2}{|c|}{$51.29 \mathrm{~B}$} & 22.08 B & $9.27 \mathrm{~B}$ & $46.47 \mathrm{~B}$ & $34.81 \mathrm{~B}$ & $5.44 \mathrm{~B}$ & \multicolumn{2}{|c|}{$21.09 \mathrm{~B}$} & $7.52 \mathrm{~B}$ \\
\hline
\end{tabular}

Lowercase letters differ within the treatment. Uppercase letters differ among the treatments; TNP $=$ Total number of pollen grain; PG $=$ Germinated pollen; TNPS $=$ Total number of pollen grain stained; $P V=$ Viable pollen grains; PNV = Non-viable pollen grains; NF = Number of flowers; NP = Number of pods; PDS = Pod set; NSP $=$ Number of seeds per pod; NAS = Number of aborted seeds; 100SW = Hundred seed mass; BSY = Bean seed yield; PS= Polen size.

the HT treatment (Table 2; Figure 1B). Genotypes IPR Tangará and IAC Sintonia also showed differences in the heat treatment. IAC Sintonia had a percentage of $15 \%$ at control and of $2 \%$ at high temperature treatment for non-viable pollen grains, whereas IPR Tangará had a percentage of $1 \%$ in the control and $13 \%$ at high temperature of non-viable pollen.

In relation to pollen grain size (PS), statistical differences were found for all the factors, heat treatment, genotype, and heat treatment $\times$ genotype interaction (Figures 1A-C). The mean values observed between the heat treatments were $53.60 \mu \mathrm{m}$ in the control treatment and $51.295 \mu \mathrm{m}$ at high temperature, meaning that high temperature reduced pollen grain size by $4 \%$, on average (Table 2). Genotypes SEA 5, IAPAR 81, IAC Diplomata, IPR Tangará, BRS Agreste, and IAC Sintonia differed in the treatments and only genotype IAPAR 81 had an increase of $4 \%$ in PS under high temperature. At high temperature, PS ranged from $45.71 \mu \mathrm{m}$ for SEA 5 genotype to $53.05 \mu \mathrm{m}$ for SER 16 genotype. Lower values for PS were observed in genotypes SEA 5, IAC Imperador, IAC Diplomata, and BRS Agreste.

\section{Meiotic behavior}

For the analysis of meiotic behavior, five of 12 twelve genotypes were selected, taking into account the differences observed for viability and pollen grain size. The analysis of the meiotic behavior of five genotypes evaluated showed the presence of 11 bivalents in diakinesis and metaphase I $(\mathrm{n}=\times=11)$.

In the analysis of the meiotic behavior, meiotic abnormalities were registered in both heat treatments; however, the HT treatment resulted in greater damage to chromosome behavior (Table 3). This analysis showed irregularities, such as the presence of polyvalents in prophase, chromosomes outside of the equatorial plate in 
the metaphasic cells (precocious chromosome), presence of late chromosome and bridge in anaphase I, irregular numbers of chromosomes at cell poles at the end of anaphase II, presence of bivalent in anaphase I, and presence of micronucleus in telophase I and II (Figure 2A-L). Because of meiotic irregularities, tetrads were observed containing microcytes with irregular sizes and the formation of dyads, triads, and polyads.

Genotypes SEA 5 and IAC Sintonia were compromised in the meiotic behavior, showing a larger number of irregularities in the control treatment. At high temperature, the greatest number of meiotic irregularities were observed in SEA 5 and IPR Tangará genotypes.

In the meiosis analysis of IAPAR 81 genotype, only normal tetrads were observed in the control treatment. However, in the HT treatment, dyads, triads with microcytes, and polyads were observed (Figures $2 \mathrm{~F}$ and $2 \mathrm{G})$. In addition, polyvalents were observed in one of the cells as well as precocious chromosomes in four cells in metaphase I.

For SEA 5 genotype, two cells showed the presence of micronucleus in telophase I in the control treatment. One cell in metaphase II showed late chromosomes that were not aligned in the equatorial plate, four cells with micronucleus in telophase II, and one cell formed of a tetrad and a microspore. In the HT treatment, the following was observed: one cell in metaphase I with a bivalent outside of the equatorial plate, two cells with bivalents that did not segregate in anaphase I, one cell at the end of anaphase II with an irregular number of chromosomes, one cell with precocious chromosome segregation in metaphase II, and the presence of triads and polyads at the end of the meiotic process (Figures $2 \mathrm{~A}, 2 \mathrm{~B}, 2 \mathrm{C}$ and 2D).

IAC Milênio genotype only had normal tetrads and no meiotic error in the control. Nevertheless, in the HT treatment, the following was observed: in metaphase I, a cell with precocious chromosome migration and another cell with polyvalent outside of the equatorial plate, cells in telophase I and II with micronuclei and the presence of dyads, tetrads with microcytes, and tetrads with microspores of various sizes (Figure 2E).

IPR Tangará did not have cells with irregular meiotic behavior and had tetrads with microspores of various sizes and triads in the control treatment. The same genotype at high temperature had late chromosomes and a bridge in anaphase I, an unequal number of chromosomes at the poles of anaphase II, irregular micronuclei and chromatin aggregates in telophase II, and the presence of dyad, triad, tetrad with microcyte, tetrads with microspores of various sizes, and polyads (Figures $2 \mathrm{H}, 2 \mathrm{I}$ and 2J).

IAC Sintonia had normal tetrads in the control treatment, one cell with polyvalent presence in prophase I, two cells with bridges, and the presence of polyvalent in metaphase I in one cell (Figures $2 \mathrm{~K}$ and $2 \mathrm{~L}$ ). In the HT treatment, meiotic irregularities were not observed, only the presence of tetrads with a microcyte.

\section{Agronomic traits}

The effect of heat treatment was found in all the traits evaluated. Significant effects for genotypes were found only for the number of seeds per plant and number of aborted seeds. There was also a pronounced effect for the interaction heat treatment $\times$ genotype for variable 100 seed weight (Table 1).

The mean number of flowers (NF) in the control treatment was 38.17 flowers per plant and 22.08 flowers per plant at high temperature, meaning that there was a decrease of $42 \%$ in NF with high temperature stress (Table 2). The mean number of flowers ranged from 36.66 for IAC Diplomata to 19.16 for SEA 5. Considering the

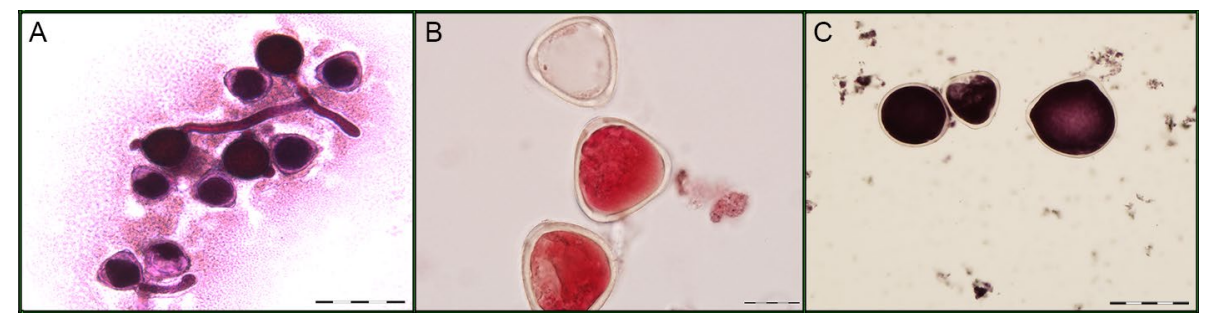

Figure $1-$ A) In vitro germination test. B) Pollen grain viability after staining with carmine acetic (stained $=$ viable; unstained $=$ non-viable). C) Pollen grains of different sizes. Bar $=20 \mu \mathrm{m}(B)$ and $50 \mu \mathrm{m}$ ( $A$ and $C$ ).

Table 3 - Meiotic index of five genotypes of dry edible bean grown under control temperature (C) and under high temperature (HT).

\begin{tabular}{|c|c|c|c|c|c|c|c|c|c|c|}
\hline \multirow{2}{*}{ Genotype } & \multicolumn{2}{|c|}{ SEA 5} & \multicolumn{2}{|c|}{ IAC Milênio } & \multicolumn{2}{|c|}{ IAPAR 81} & \multicolumn{2}{|c|}{ IPR Tangará } & \multicolumn{2}{|c|}{ IAC Sintonia } \\
\hline & $C$ & HT & C & HT & $C$ & $\mathrm{HT}$ & C & HT & C & HT \\
\hline Normal Tetrads & - & 155 & 219 & 122 & 87 & 175 & 286 & 194 & 180 & 90 \\
\hline Abnormal Tetrads & - & 5 & 0 & 11 & 0 & 60 & 5 & 7 & 0 & 1 \\
\hline Total of post meiotic product & - & 160 & 219 & 133 & 87 & 235 & 291 & 201 & 180 & 91 \\
\hline Ml (\%) & - & 96.875 & 100 & 91.729 & 100 & 74.468 & 98.282 & 96.517 & 100 & 98.901 \\
\hline
\end{tabular}




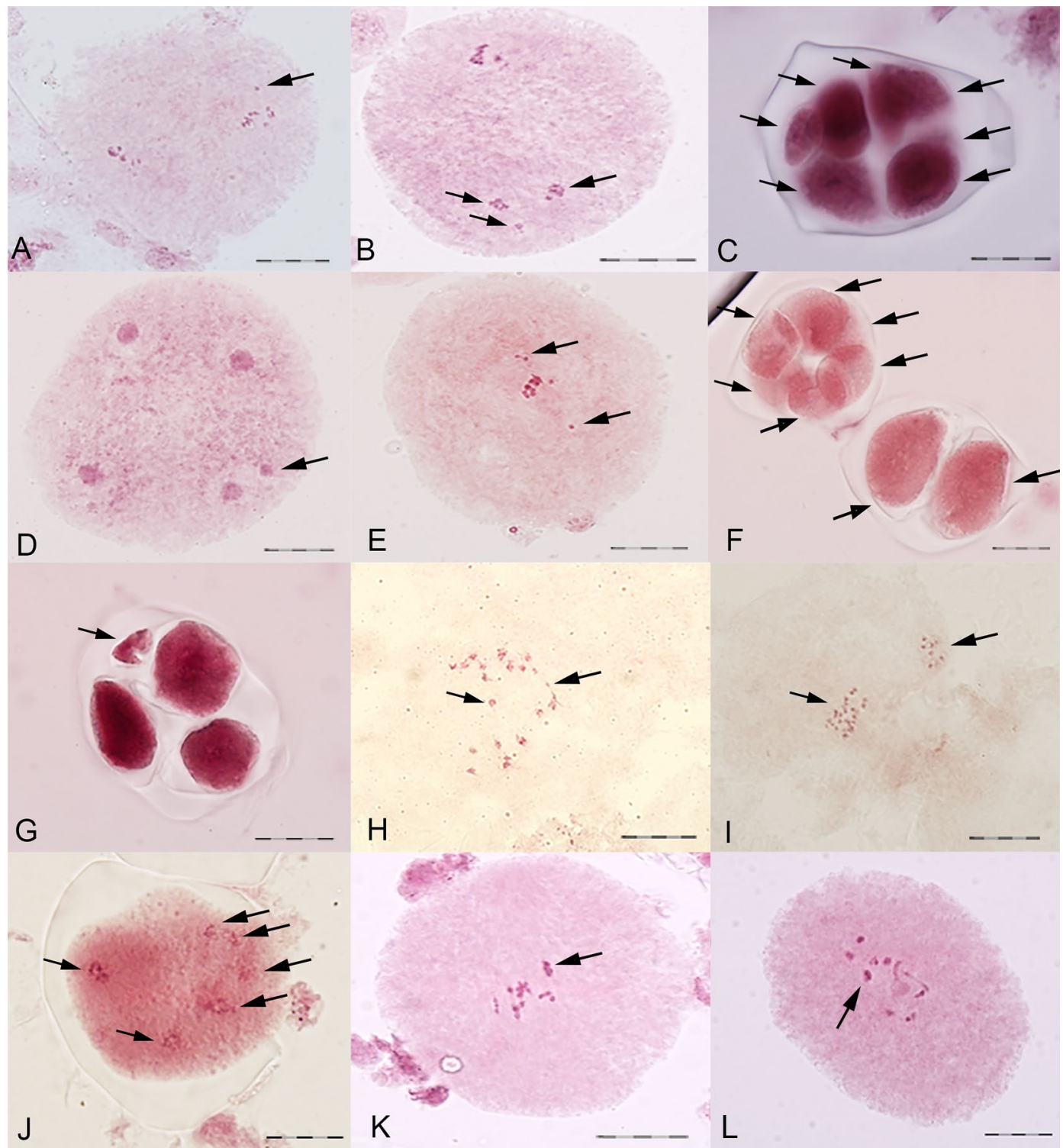

Figure 2 - Irregularities in meiosis of five genotypes of Phaseolus vulgaris. Genotype: SEA 5: A) Metaphase II with division of the poles at different times and chromosomes not aligned in the equatorial plate. B) Anaphase II with precocious chromosomes. C) Polyad. D) Telophase II with micronucleus. Genotype: IAC Milênio: E) Metaphase I with precocious chromosomes; Genotype IAPAR 81: F) Polyad and dyad. G) Triad with a microcyte; Genotype IPR Tangará: H) Anaphase I with late chromosome and bridge. I) Anaphase II with unequal number of chromosomes in the equatorial plates. J) Telophase II with irregular distribution of chromatin at the poles; Genotype IAC Sintonia: K) Metaphase I with polyvalent. L) Prophase I with polyvalent. Bar $=20 \mu \mathrm{m}$.

high temperature treatment, IAC Imperador genotype had the highest mean, 36 flowers per plant, and SEA 5 genotype had the lowest mean, 14.67 flowers per plant.

Similar behavior was found in relation to the number of pods (NP). The mean value of NP in the control treatment was 12.50 and 9.28 in the HT treatment, corresponding to a reduction of $26 \%$ of NP with induction of heat stress (Table 2). The number of pod formation ranged from 13.33 pods per plant for IAC Imperador genotype to seven pods for SEA 5 genotype. Under high temperature, the largest number of pod formation was observed for IAC Imperador genotype with a mean of 14.67 pods per plant, and the smallest formation for IPR Tangará genotype with a mean of six pods per plant.

The percentage of pod set was calculated by the total number of pods formed in relation to the total number of flowers produced in which, in general, a low rate of pod set was observed, with $35 \%$ in the control treatment and $47 \%$ in the HT treatment (Table 2). The greater pod set percentage (PDS) observed under heat 
stress occurred due to formation of fewer flowers under this condition. This characteristic ranged from 55.19 for BRS Estilo genotype to 27.98 for IPR Tangará genotype. At high temperature, percentage of pod set ranged from $65 \%$ observed in SER 16 genotype to $24 \%$ in IPR Tangará genotype. According to Lavania et al. (2015), the great loss of flowers observed in fava beans results from the combination of plant attributes with environmental factors, such as drought and high temperatures.

The number of seeds per plant (NSP) exhibited significant differences for both the heat treatment factor and the genotype factor. A mean reduction of $37 \%$ was found in seed production considering the HT treatment in relation to the control, with mean values of 34.81 and 55.69 seeds per plant, respectively. The genotypes that had greater mean formation of seeds were FT Nobre, IAC Imperador, BRS Estilo, and IAC Diplomata, with $71.17,54.17,53.50$, and 52.33 seeds per plant, respectively (Table 2).

The number of aborted seeds (NAS) showed significant effects of the heat treatment and genotypes, with a reduction of the number of aborted seeds. In other words, the number of empty locules in the pods, with mean values 8.47 aborted seeds per plant for the control treatment and 5.27 aborted seeds per plant for the HT treatment (Table 2). Four genotypes differed statistically from the others, exhibiting higher seed abortion rates, greater than 8.5 aborted seeds per plant, namely IAC Imperador, IAPAR 81, IPR Tangará, and IAC Sintonia, with mean values $16.33,12.5,9.5$, and 8.5 aborted seeds per plant, respectively.

The variable 100 seed weight (100SW) had a reduction of $28 \%$ under high temperature; the mean value was $29.14 \mathrm{~g}$ in the control treatment and $21.09 \mathrm{~g}$ in the HT treatment (Table 2). Although no statistical difference was detected for the genotype factor, an effect was observed for the heat treatment $\times$ genotype interaction, that is, the behavior of the genotypes differed in response to the treatments. The genotypes that differed between the treatments were SER 16, IAC Milênio, BRS Estilo, IPR Tangará, and IAC Sintonia, with reductions of $30 \%, 12 \%, 31 \%, 54 \%$, and $53 \%$, respectively, in seed weight with the imposition of heat treatment. At high temperature, genotypes Pérola $(25.78 \mathrm{~g})$, IAPAR 81 (25.17 g), IAC Diplomata (24.72 g), and IAC Imperador $(24.30 \mathrm{~g})$ showed the highest weights, while the lowest mean weight (14.76 g) was observed in genotype IPR Tangará.

Bean seed yield was influenced only by the heat treatment factor, with mean values $16.39 \mathrm{~g}$ per plant for the control treatment and $7.46 \mathrm{~g}$ per plant for the high temperature treatment, meaning that a mean yield reduction of $46 \%$ was observed with heat imposition. Mean yield of both heat treatments ranged from 15.60 $\mathrm{g}$ per plant for FT Nobre genotype to $8.85 \mathrm{~g}$ per plant for IAPAR 81 genotype. Genotypes IAC Imperador, IAC Diplomata, FT Nobre, Pérola e BRS Estilo stood out when subjected to high temperature (Figure 3), exhibit-

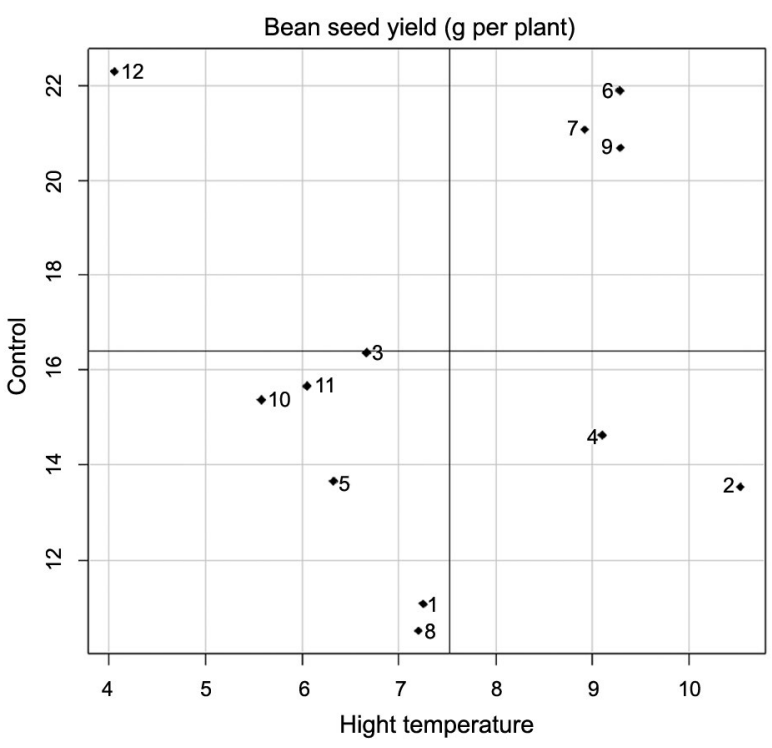

Figure 3 - Mean performance of bean seed yield (g per plant) of 12 genotypes of dry edible bean grown under control and high temperature. Axis of the abscissa represents the high temperature heat treatment and axis of the ordinate represents the control heat treatment. The genotypes evaluated in this study were 1-SEA 5, 2-IAC Imperador, 3-SER 16, 4-Pérola, 5-IAC Milênio, 6-FT Nobre, 7-BRS Estilo, 8-IAPAR 81, 9-IAC Diplomata, 10-IPR Tangará, 11BRS Agreste, and 12-IAC Sintonia.

ing mean yields above the overall yield of the genotypes at $10.53 \mathrm{~g}, 9.29 \mathrm{~g}, 9.29 \mathrm{~g}, 9.11 \mathrm{~g}$ and $8.91 \mathrm{~g}$. In the control treatment, IAC Sintonia genotype exceeded the overall mean of the genotypes, at $22.30 \mathrm{~g}$ per plant, showing rather high productivity under ideal crop conditions. Genotypes FT Nobre, BRS Estilo, and IAC Diplomata stood out in both heat treatments, exhibiting mean values above the overall mean of the genotypes under both heat treatments.

\section{Discussion}

The staining method, performed through the staining of the cell content in the pollen grain, is considered a less accurate method for detecting pollen viability. In this study, this technique was complemented with the pollen germination method for 12 genotypes evaluated.

The influence of high temperature on the total number of pollen grains assessed was observed when the germination technique was used in relation to the staining technique. Reduction in the total number of pollen grains in the germination technique can be explained not only by the counting methods adopted (i.e. counting performed only in some fields of the slide and counting performed in the entire slide), but also through inhibition that may have occurred of anther dehiscence characterized by closing of locules, as reported by Zinn et al. (2010). In the germination technique, the slides were set up by detachment of the pollen grains with 
a brush, whereas when the staining technique is applied, anthers are excised by maceration. Thus, we can infer that this reduction found at high temperature by the germination technique may have resulted from the lack of detachment of the pollen grains and, consequently, in production of the gametes.

In the HT treatment, a greater tendency to germination of pollen tubes was observed in relation to the control. The genotypes that increased germination in response to high temperature were SER 16, IAC Sintonia, IAC Diplomata, and IAPAR 81.

Jiang et al. (2015) studied the behavior of two pea genotypes under five high temperature regimes and found influence of the treatments on germination reduction of the pollen grain. This is contrary to the results presented here in which pollen germination was not statistically influenced by temperature and there was an increase in the mean of germinated pollen grains under temperature stress. In addition, the authors also reported a size reduction of the pollen tube, pod size, number of seeds per pod, and in the seed-ovule ratio.

Statistically, the rate of pollen germination was not affected by the heat treatment; nevertheless, pollen germination ranged from $0.6 \%$ to $11 \%$ in the control treatment and from $0.4 \%$ to $17 \%$ in the HT treatment. These numbers show a tendency toward higher germination in the HT treatment, with a mean increase of $33 \%$ in relation to the control treatment. Germination increased under high temperature for genotypes SER 16, IAC Sintonia, IAC Diplomata, and IAPAR 81.

According to Zinn et al. (2010), the effects of temperature stress on male reproductive structures are well known, as described for the wheat crop, in which stress of high temperature in the meiosis period can lead to degradation of the tapetum, which leads to pollen sterility. In tomato and rice, high temperatures can cause reduction in anther dehiscence, reducing pollen dispersal. The effect of high temperature on the reproductive phase can directly affect development of male and female gametes, and the effects on male gametes are much better documented for numerous plant species, revealing the negative effects on maturation, viability, pollen grain germination, and pollen tube growth.

The estimates of pollen viability through the staining technique revealed that, except for genotypes IAC Imperador, IPR Tangará, and IAC Sintonia, the genotypes exhibited viability greater than $90 \%$, even when subjected to the HT treatment. IAC Imperador showed mean viability of $88 \%$ for both heat treatments, meaning that it remained stable regardless of the condition received and it was the genotype with the best yield performance at high temperature.

According to Giorno et al. (2013), in the reproductive development in various species, the processes reported as very sensitive to high temperature include meiosis in the male and female organs, pollen germination, pollen tube growth, pollen/pistil interactions, fertilization and post-fertilization processes, endosperm formation, and embryonic development. Changes in temperature that occur during the flowering period can induce morphological changes in flower organs, specifically pollen development during meiosis. These changes depend on the intensity, duration, and rate of temperature increase.

The meiotic index of five genotypes studied corroborates the data obtained for pollen viability of the same genotypes in which the high percentage of viable grains results in a high percentage of normal tetrads. The analysis of meiotic behavior of five genotypes evaluated revealed the presence of 11 bivalents, as observed by Weinstein (1926), Fonseca et al. (2010), Dalla Nora et al. (2014) and Pozzobon et al. (2015).

The two heat treatments resulted in a mean percentage greater than $90 \%$ for normal tetrads, in relation to abnormal tetrads (dyad, triad, and polyad), except for genotypes SEA 5, which did not have tetrads in the control treatment, and IAPAR 81, which exhibited a lower percentage of normal tetrads $(74 \%)$ in the HT treatment. The highest percentages of normal tetrads were observed for genotypes IAC Milênio, IAPAR 81, IPR Tangará, and IAC Sintonia, ranging from $100 \%$ to $98 \%$ in the control treatment, and from $99 \%$ to $74 \%$ in the HT treatment. Dalla Nora et al. (2014) observed similar values for bean genotypes. The authors aimed to determine the meiotic behavior and estimate viability of pollen grains in seven bean cultivars grown in a greenhouse without imposed heat stress. These authors found that all genotypes had high meiotic indexes, $96 \%$ mean, without the occurrence of abnormalities, and therefore with the formation of viable pollen grains. This was also observed in the analyses of pollen viability estimation, with $99 \%$ mean, and a variation in the mean size of the pollen grain from 51 to $66 \mu \mathrm{m}$.

The HT treatment induced a greater number of irregularities in meiosis and genotypes SEA 5 and IPR Tangará were the most sensitive to heat. In addition, IPR Tangará genotype had the lowest rate of pod set, associated with low yield performance, meaning that its bean seed yield was less than the mean of 12 genotypes. Genotype SEA 5 not only had irregularities under both heat treatments, but it also had the lowest mean number of flowers and pods produced and thus low yield performance under both heat treatments.

Our experiments also showed that influence of high temperature on the reproduction process and on fertilization and post-fertilization processes resulted in reduction in flowers produced, pod development, and seed formation, as described in the literature. According to Kaushal (2016), exposure to high temperatures causes a series of morpho-anatomical, physiological, and biochemical changes that affect growth and development, reduce life cycle, and increase senescence, compromising yields.

The imposition of stress by high temperature showed reductions of $42 \%$ in flower production, $26 \%$ in number of pods, $38 \%$ in number of seeds, and $35.8 \%$ in number of aborted seeds. Therefore, under the heat stress condition, there was reduction in pod and seed produc- 
tion, but there were also a lower rate of seed abortion, reduction of $28 \%$ in 100 seed weight, and a stress intensity index of 0.54 , calculated according to Fisher and Maurer (1978), that is, mean yield decrease drastically by $54 \%$. According to Porch et al. (2010), mean maximum daily temperatures above $30{ }^{\circ} \mathrm{C}$ and nighttime temperatures above $20^{\circ} \mathrm{C}$ can significantly affect bean yield in the tropics, resulting in excessive abortion of buds, flowers, and pods and seed abortion inside the pod. As observed in this study, this results in the formation of small bean pods, without seeds, and significant yield reduction.

High reduction in performance of production components and yield under high temperature resulted in no differentiation of genotypes by the mean testing regarding the following variables: number of pods, number of seeds, 100 seed weight, and bean seed yield. Nevertheless, it was possible to select the genotypes most adapted to the high temperature condition by the mean yield performance in which genotypes IAC Imperador, FT Nobre, Pérola, BRS Estilo, and IAC Diplomata stood out with mean values above the overall mean of 12 genotypes at high temperature, that is, greater than $7.52 \mathrm{~g}$ per plant.

\section{Conclusions}

The heat treatment affects most traits evaluated and results in losses in pollen grain formation, reduction in number and size of pollen grains, greater abortion of flowers and, consequently, formation of fewer pods and drastic reduction in bean seed yield.

The meiotic index corroborates the pollen viability data. The high percentage of viable pollen grains results in a high percentage of normal tetrads and the control treatment exhibited higher percentages of normal tetrads.

Meiotic errors are more numerous due to imposition of the high temperature treatment.

Genotypes with the highest yields at high temperature were IAC Imperador, FT Nobre, Pérola, BRS Estilo, and IAC Diplomata.

\section{Acknowledgements}

FAPESP - Fundação de Amparo à Pesquisa do Estado de São Paulo. CAPES - Coordenação de Aperfeiçoamento de Pessoal de Nível Superior. CNPq - Conselho Nacional de Desenvolvimento Científico e Tecnológico.

\section{Authors' Contributions}

Conceptualization: Silva, D.A.; Chiorato, A.F.; Pinto-Maglio, C.A.F.; Reis, R.L.M.; Carbonell, S.A.M. Data acquisition: Silva, D.A.; Oliveira, E.C.; Reis, R.L.M. Data analysis: Silva, D.A.; Chiorato, A.F.; Pinto-Maglio, C.A.F.; Oliveira, E.C. Design of methodology: Silva, D.A. Writing and editing: Silva, D.A.; Pinto-Maglio, C.A.F.; Oliveira, E.C.; Chiorato, A.F.; Reis, R.L.M.; Carbonell, S.A.M.

\section{References}

Alexander, M.P. 2009. A versatile stain for pollen, fungi, yeast and bacteria. Stain Technology 55: 13-18.

Conger, A. 1953. Culture of pollen tubes for chromosomal analysis at the pollen tube division. Stain Technology 286: 289-293.

Consultative Group on International Agricultural Research [CGIAR]. 2015. Developing beans that can beat the heat. Available at: www.cgiar.org [Accessed Feb 27, 2018]

Dalla Nora, G.; Tedesco, S.B.; Pastori, T.; Frescura, V.D.; Ribeiro, N.D.; Laughinghouse, H.D.; Lopes, S.J.; Schifino-Wittmann, M.T. 2014. Meiotic behavior and pollinic viability in bean cultivars. Biocell 38: 33-38.

Ernest, E.G.; Wisser, R.J.; Johnson, G.C. 2017. Physiological Effects of Heat Stress on Lima Bean (Phaseolus lunatus) and Development of Heat Tolerance Screening Techniques. USDAARS, Washington, DC, USA.

Giorno, F.; Wolters-Arts, M.; Mariani, C.; Rieu, I. 2013. Ensuring reproduction at high temperatures: the heat stress response during anther and pollen development. Plants 2: 489-506.

Hatfield, J.L.; Prueger, J.H. 2015. Temperature extremes: effect on plant growth and development. Weather and Climate Extremes 10: 4-10.

Jiang, Y.; Lahlali, R.; Karunakaran, C.; Kumar, S.; Davis, A.R.; Bueckert, R.A. 2015. Seed set, pollen morphology and pollen surface composition response to heat stress in field pea. Plant, Cell and Environment 38: 2387-2397.

Kaushal, N.; Bhandari1, K.; Siddique, H.M.K.; Nayyar, H. 2016. Food crops face rising temperatures: an overview of responses, adaptive mechanisms, and approaches to improve heat tolerance. Cogent Food \& Agriculture 2: 1134380.

Lavania, D.; Siddiqui, M.H.; Al-Whaibi, M.H.; Singh, A.K.; Kumar, R.; Grover, A. 2015. Genetic approaches for breeding heat stress tolerance in faba bean (Vicia faba L.). Acta Physiologiae Plantarum 37: 1737.

Monterroso, V.A.; Wien, W.C. 1990. Flower and pod abscission due to heat stress in beans. Journal of the American Society for Horticultural Science 115: 631-634.

Ofir, M.; Gross, Y.; Bangerth, F.; Kige, J. 1993. High temperature effects on pod and seed production as related to hormone levels and abscission of reproductive structures in common bean (Phaseolus vulgaris L.). Scientia Horticulturae 55: 201-211.

Omae, H.; Kumar, A.; Shono, M. 2012. Adaptation to high temperature and water deficit in the common bean (Phaseolus vulgaris L.) during the reproductive period. Journal of Botany 2012: article 803413.

Porch, T.G.; Smith, J.R.; Beaver, J.S.; Griffiths, P.D.; Canaday, C.H. 2010. TARS-HT1 and TARS-HT2 heat-tolerant dry bean germplasm. HortScience 45: 1278-1280.

Zinn, K.E.; Tunc-Ozdemir, M.; Harper, J.F. 2010. Temperature stress and plant sexual reproduction: uncovering the weakest links. Journal of Experimental Botany 61: 1959-1968. 